\title{
ANALISIS PERAN KOMISI PEMILIHAN UMUM DALAM PENETAPAN DAFTAR PEMILIH TETAP PADA PEMILU SERENTAK TAHUN 2020
}

\author{
Faharudin \\ Universitas Dayanu Ikhsnauddin, Jalan Dayanu Ikhsanuddin No. 124 Baubau, \\ faharudin@unidayan.ac.id
}

\begin{abstract}
ABSTRAK
Penelitian ini bertujuan Untuk mengetahui tentang peran Komisi Pemilihan Umum Daerah Kota Baubau dalam penetapan Daftar Pemilih Tetap pada Pemilu serentak tahun 2019, serta mengetahui hal-hal yang menjadi faktor penghambat dalam penetapan Daftar Pemilih Tetap pada Pemilu serentak tahun 2020. Penelitian dilaksanakan di Kantor KPUD, dengan menggunakan metode data primer dan data sekunder.

Hasil yang diperoleh dari penelitian adalah (1) Peran KPUD Kota Baubau dalam Penetapan Daftar Pemilih tetap (DPT) yaituh memutakhirkan, menyusun, hingga menetapkan DPT dimana dalam prosesnya cukup panjang dan berjenjang antara proses satu dengan lainnya, dimulai dari penyandingan daftar pemilih terakhir dengan DP4 hasil sinkronisasi oleh KPU, yang selanjutnya di lakukan pemutakhiran data pemilih (pencocokan dan penelitian) kemudian oleh Panitia Pemungutan Suara (PPS) menyusun dan memutakhirkan Daftar Pemilih Sementara (DPS), Setelah penetapan DPS, melalui perbaikan di hasilkanlah Daftar Pemilih Sementara Hasil Perbaikan (DPSHP), begitu juga berlaku pada DPSHP hingga terbentuklah DPSHP Akhir, dari DPSHP Akhir ini kemudian oleh KPUD Kota Baubau merekapitulasi dan di menetapkan Daftar Pemilih Tetap (DPT).
\end{abstract}

\section{Kata Kunci : DPT, Pemilu, KPUD}

\begin{abstract}
This study aims to find out about the role of the Regional Election Commission of Baubau City in the determination of the Permanent Voters List in the simultaneous Election in 2020, and to know things that are the inhibiting factors in the determination of the Permanent Voters List in simultaneous elections in 2019 in the City of Baubau. The study was conducted at the Baubau City Election Commission Office, using primary data and secondary data methods.

The results obtained from the study are (1) The role of the Baubau City Election Commission in the Determination of the Permanent Voters List (DPT) is to update, compile, and determine the DPT where the process is quite long and tiered between one another, starting from the final voter list with DP4 the results of synchronization by the $K P U$, which are then updated by voter data (matching and research) then by the Voting Committee (PPS) to compile and update the Temporary Voters List (DPS), After stipulating the DPS, through repairs a temporary Voters List is produced (DPSHP), so also applies to DPSHP until the Final DPSHP is formed, from this Final DPSHP then by Baubau City KPUD recapitulates and sets the Permanent Voters List (DPT).
\end{abstract}




\section{Keywords: DPT, Pemilu, KPUD}

\section{PENDAHULUAN}

Pemilihan Umum merupakan pranata terpenting dalam tiap negara demokrasi, terlebih lagi bagi negara yang berbentuk Republik seperti Indonesia. Pranata itu berfungsi untuk memenuhi tiga prinsip pokok demokrasi, yaitu kedaulatan rakyat, keabsahan pemerintahan, dan pergantian pemerintahan secara teratur. Ketiga prinsip tersebut bertujuan untuk menjamin terjaga dan terlaksananya cita-cita kemerdekaan, mencegah bercokolnya kepentingan tertentu di dalam tubuh tertentu di dalam kepentingan tertentu di dalam pemerintahan, atau digantikannya kedaulatan rakyat menjadi kedaulatan penguasa. ${ }^{1}$

Salah satu unsur yang terpenting dalam Pemilihan Umum adalah suara rakyat di suatu daerah yang melaksanakan pemilihan. Pemilihan Umum dikatakan tidak berhasil jika rakyat sebagai unsur penting dalam pemilu tidak menyalurkan suara dan aspirasinya untuk menentukan calon pemimpin yang akan memimpin dirinya, karna rakyat adalah unsur pokok negara. Didalam sistem pemilihan umum di Indonesia, seseorang bisa menggunakan hak pilihnya jika sudah terdaftar dalam Daftar Pemilih Tetap (DPT). Namun Daftar Pemilih Tetap (DPT) selalu menjadi permasalahan dalam tahapan Pemilihan Umum.

Dilihat dari siklus pemilu yang umum diterapkan dalam pelaksanaan pemilu, maka pengelolaan data pemilih menjadi tahapan krusial pertama dalam siklus itu. Data pemilih pemilu menjadi bagian terpenting karena data pemilih yang hasil akhirnya berupa Daftar Pemilih Tetap merupakan representasi dari diakuinya hak pilih yang berlaku bagi seluruh warga negara pada negara demokrasi. ${ }^{2}$

Sebelum ditetapkan Daftar Pemilih Tetap, terlebih dahulu ditetapkan Daftar Pemilih Sementara (DPS) Daftar Pemilih Sementara yaitu Pemilih hasil pemutakhiran DP4 dan Daftar Pemilih pada Pemilihan Umum atau Pemilihan Terakhir. Menurut pasal 1 ayat 36 Peraturan Komisi Pemilihan Umum Nomor 11 Tahun 2018 Tentang Penyusunan Daftar Pemilih di Dalam Negeri Dalam Penyelenggaraan Pemilihan Umum yang selanjutnya disingkat DPT adalah DPSHP akhir yang telah diperbaiki oleh PPS, di rekapitulasi oleh PPK, dan ditetapkan oleh KPU/KIP Kabupaten/Kota.

Adapun persyaratan yang harus dipenuhi sebagai pemilih diatur dalam pasal 4 Peraturan Komisi Pemilihan Umum Nomor 11 Tahun 2018 tentang Penyusunan Daftar Pemilih di Dalam Negeri Dalam Penyelenggaraan Pemilihan Umum, untuk dapat menggunakan hak pilihnya Warga Negara Indonesia harus terdaftar sebagai pemilih dan memenuhi syarat sebagai berikut:

1. Genap berusia 17 (tujuh belas) tahun atau lebih pada hari pemungutan suara atau sudah/pernah kawin

2. Tidak sedang terganggu jiwa/ingatannya

3. Tidak sedang dicabut hak pilihnya berdasarkan putusan pengadilan yang telah mempunyai kekuatan hukum tetap

4. Berdomisili di wilayah administratif pemilih yang dibuktikan dengan KTP-el

\footnotetext{
${ }^{1}$ Mukthie Fadjar, "Pemilu, Perselisihan Hasil Pemilu dan Demokrasi", (Malang: Setara Press, 2013). Hlm.1.

${ }^{2}$ Luki Sandra Amalia, Syamsuddin Haris, Sri nur yanti, Lili Romli, Devi Darmawan,

2016, Evealuasi Pemilu Legislatif 2014 : Analisi Proses dan Hasil, Pustaka Pelajar,

Yogyakarta, hlm.30
} 


\section{ANALISIS PERAN KOMISI PEMILIHAN UMUM DALAM PENETAPAN DAFTAR PEMILIH TETAP PADA PEMILU SERENTAK TAHUN 2020- Faharudin}

5. Dalam hal pemilih belum mempunyai KTP-el, sebagaimana dimaksud dalam nomor 4, dapat menggunakan Surat Keterangan yang diterbitkan dinas yang menyelenggarakan urusan kependudukan dan catatan sipil setempat

6. Tidak sedang menjadi anggota Tentara Nasional Indonesia atau Kepolisian Negara Republik Indonesia

KPU Kabupaten/Kota juga bertugas melakukan dan mengumumkan rekapitulasi hasil penghitungan suara Pemilu anggota DPR, anggota DPD, Pemilu Presiden dan Wakil Presiden, dan anggota DPRD provinsi serta anggota DPRD kabupaten/kota yang bersangkutan berdasarkan berita acara hasil rekapitulasi suara di PPK; Membuat berita acara penghitungan suara dan sertifikat penghitungan suara serta wajib menyerahkannya kepada saksi Peserta Pemilu, Bawaslu Kabupaten/Kota, dan KPU Provinsi; Mengumumkan calon anggota DPRD kabupaten/kota terpilih sesuai dengan alokasi jumlah kursi setiap daerah pemilihan di kabupaten/kota yang bersangkutan dan membuat berita acaranya; Menindaklanjuti dengan segera temuan dan laporan yang disampaikan oleh Bawaslu Kabupaten/Kota; Menyosialisasikan Penyelenggaraan Pemilu dan/atau yang berkaitan dengan tugas dan wewenang KPU Kabupaten/Kota kepada masyarakat; Melakukan evaluasi dan membuat laporan setiap tahapan Penyelenggaraan Pemilu; dan melaksanakan tugas lain yang diberikan oleh KPU, KPU Provinsi, dan/atau ketentuan peraturan perundang-undangan. ${ }^{3}$

Berdasarkan Undang-undang Nomor 7 tahun 2017 tentang pemilihan umum sebagaimana di singgung di atas mengenai tugas KPU Kabupaten/Kota, yakni memutakhirkan data pemilih berdasarkan data pemilu terakhir dengan memperhatikan data kependudukan yang disiapkan dan diserahkan oleh pemerintah dan menetapkannya sebagai daftar pemilih bahwasanya pemutakhiran sampai kepada penetapan daftar pemilih sangat penting dan krusial dimana masyarakat yang akan menyalurkan hak pilihnya harus terdaftar dalam DPT guna kelancaran dalam proses pemilihan.

Tidak sedikit realitas di lapangan ditemukan bahwa hingga pada hari pemungutan suara masih ada saja masyarakat yang belum terdaftar dalam DPT.

\section{A. Perumusan Masalah}

Berdasarkan latar belakang di atas, maka dapat disimpulkan rumusan masalah sebagai berikut: Bagaimana Peran Komisi Pemilihan Umum Daerah Kota Baubau dalam penetapan Daftar Pemilih Tetap pada Pemilu serentak tahun 2020.?

\section{B. Landasan Teoritis}

\section{Pengertian Peran}

Teori peran (Role Theory) adalah teori yang merupakan perpaduan antara teori, orientasi, maupun disiplin ilmu. Istilah "peran" diambil dari dunia teater. Dalam teater, seorang aktor harus bermain sebagai seorang tokoh tertentu dan dalam posisinya sebagai tokoh itu ia diharapkan untuk berperilaku secara tertentu. Posisi aktor dalam teater (sandiwara) itu kemudian dianologikan dengan posisi seseorang dalam masyarakat. Sebagaimana halnya dalam teater, posisi orang dalam masyarakat sama dengan posisi aktor dalam teater, yaitu bahwa perilaku yang diharapkan daripadanya tidak berdiri sendiri, melainkan selalu berada dalam kaitan dengan adanya orang-orang lain yang berhubungan dengan orang atau aktor

\footnotetext{
${ }^{3}$ Pasal 18 Undang Undang No 7 tahun 2017 tentang Pemilihan Umum.
} 
tersebut. Dari sudut pandang inilah disusun teori-teori peran. ${ }^{4}$

Kahn et mengenalkan teori peran pada literatur perilaku organisasi. Mereka menyatakan bahwa sebuah lingkungan organisasi dapat mempengaruhi harapan setiap individu mengenai perilaku peran mereka. Harapan tersebut meliputi normanorma atau tekanan untuk bertindak dalam cara tertentu. Individu akan menerima pesan tersebut, menginterpretasikannya, dan merespon dalam berbagai cara. Masalah akan muncul ketika pesan yang dikirim tersebut tidak jelas, tidak secara langsung, tidak dapat diinterpretasikan dengan mudah, dan tidak sesuai dengan daya tangkap si penerima pesan. Akibatnya, pesan tersebut dinilai ambigu atau mengandung unsur konflik. Ketika hal itu terjadi, individu akan merespon pesan tersebut dalam cara yang tidak diharapkan oleh si pengirim pesan. ${ }^{5}$

Peran merupakan aspek yang dinamis dari kududukan (status). Apabila seseorang melaksanakan hak dan kewajibannya sesuai dengan kedudukannya, maka hal ini berarti ia menjalankan suatu peranan. Keduanya tidak dapat dipisah-pisahkan dan saling bertentangan satu sama lain. Setiap orang mempunyai macam- macam peranan yang berasal dari pola-pola pergaulan hidupnya. Hal tersebut sekaligus berarti bahwa "peranan menentukan apa yang diperbuatnya bagi masyarakat kepadanya. Peranan lebih banyak menekankan pada fungsi, penyesuaian diri dan sebagai suatu proses". ${ }^{6}$

Menurut Abdulsyani, "Peran adalah suatu perbuatan seseorang atau sekelompok orang dengan cara tertentu dalam usaha menjalankan hak dan kewajibannya sesuai dengan status yang dimilikinya". Pelaku peranan dikatakan berperan jika telah melaksanakan hak dan kewajibannya sesuai dengan status sosialnya dengan masyarakat. Jika seseoarang mempunyai status tertentu dalam kehidupan masyarakat, maka selanjutnya akan ada kecenderungan akan timbul suatu harapan-harapan baru. ${ }^{7}$

Menurut Soerjono Soekanto, unsur-unsur peranan atau role adalah:

a. Aspek dinamis dari kedudukan

b. Perangkat hak-hak dan kewajiban

c. Perilaku sosial dari pemegang kedudukan

d. Bagian dari aktivitas yang dimainkan seseorang. ${ }^{9}$

Hubungan-hubungan sosial yang ada dalam masyarakat, merupakan hubungan antara peranan-peranan individu dalam masyarakat. Sementara peranan itu sendiri diatur oleh norma-norma yang berlaku dalam masyarakat. Jadi seseorang menduduki suatu posisi dalam masyarakat serta menjalankan suatu peranan. Menurut Soerjono Soekanto (2002 :246) peranan mencakup tiga hal, yaitu:

a. Peranan meliputi norma-norma yang dihubungkan dengan posisi atau tempat seseorang dalam masyarakat. Peranan dalam arti ini merupakan rangkaian peraturan-peraturan yang membimbing seseorang dalam kehidupan kemasyarakatan peranan adalah suatu konsep tentang apa

${ }^{4}$ Gartiria Hutami, Pengaruh Konflik Peran Dan Ambiguitas Peran Terhadap Komitmen Independensi Auditor Internal Pemerintah Daerah (Studi Empiris Pada Inspektorat Kota Semarang) (Universitas Diponegoro, Jurnal). Hlm.5.

${ }^{5}$ Ibid

${ }^{6}$ Soerjono Soekanto, sosiologi suatu pengantar, (Raja Grafindo Persada,2002), Hlm.268-269.

${ }^{7}$ Abdulsyani, sosiologi,skematika,teori, dan Terapan, (Jakarta: PT bumi aksara, 2012), Hlm.94. 


\section{ANALISIS PERAN KOMISI PEMILIHAN UMUM DALAM PENETAPAN DAFTAR PEMILIH TETAP PADA PEMILU SERENTAK TAHUN 2020- Faharudin}

yang dapat dilakukan oleh individu dalam masyarakat sebagai organisasi

b. Peranan juga dapat dikatakan sebagai perilaku individu yang penting bagi struktur sosial masyarakat. ${ }^{8}$

2.

Pemilihan Umum

Pada dasarnya yang dimaksud dengan pemilu adalah proses pemilihan orangorang untuk mengisi jabatan-jabatan politik tertentu. Menurut Undang Undang Nomor 7 Tahun 2017 (selanjutnya ditulis UU 7/2017) tentang Pemilihan Umum, Pemilihan Umum yang selanjutnya disebut Pemilu adalah sarana kedaulatan rakyat untuk memilih anggota Dewan Perwakilan Rakyat, anggota Dewan Perwakilan Daerah, Presiden dan Wakil Presiden, dan untuk memilih anggota Dewan Perwakilan Rakyat Daerah, yang dilaksanakan secara langsung, umum, bebas, rahasia, jujur, dan adil dalam Negara Kesatuan Republik Indonesia berdasarkan Pancasila dan UndangUndang Dasar Negara Republik Indonesia Tahun $1945 .^{9}$

Perubahan ketentuan Pasal 1 ayat (2) UUD 1945 dari yang semula berbunyi "Kedaulatan adalah ditangan rakyat, dan dilakukan sepenuhnya oleh Majelis Permusyawaratan Rakyat"menjadi "Kedaulatan berada di tangan rakyat dan dilaksanakan menurut Undang-Undang Dasar"menunjukan terjadinya perubahan gagasan yang begitu mendasar tentang kedaulatan rakyat dalam UUD 1945. Terjadi pergeseran yang sangat fundamental tentang siapa sebenarnya yang bertindak sebagai pemegang supremasi atau kekuasaan tertinggi. Sebagaimana dikemukakan Soewoto Mulyosudarmo, perubahan Pasal 1 ayat (2) UUD 1945 merupakan perubahan menuju sebuah kondisi yang mencerminkan keadaan yang sebenarnya mengatur tentang kekuasaan tertinggi. ${ }^{10}$ Di mana pemilik kekuasaan tertinggi dalam negara adalah rakyat yang pelaksanaannya sesuai dengan Undang-Undang Dasar.

Moh.Kusnardi dan Harmailly Ibrahim mengemukakan bahwa dalam paham kedaulatan rakyat (democracy), rakyatlah yang dianggap sebagai pemilik atau pemegang kekuasaan tertinggi dalam suatu negara. ${ }^{11}$ Rakyatlah yang menentukan corak dan bagaimana cara pemerintahan diselenggarakan. Rakyat jugalah yang menetukan tujuan yang hendak dicapai oleh negara dan pemerintahannya itu.Berdasarkan hal tersebut maka diadakanlah pemilihan umum yang yang bertujuan untuk melaksanakan kedaulatan rakyat dimana rakyat memilih siapa yang berhak menjadi pemimpin bagi mereka.

3.

Asas-Asas Pemilihan Umum

Pasal 22E ayat (1) Undang-undang Dasar Negara Republik Indonesia Tahun 1945 berisi ketentuan bahwa pemilihan umum dilaksanakan secara langsung, umum, bebas, rahasia, jujur dan adil. Berdasarkan ketentuan tersebut, maka asas pemilihan umum adalah langsung, umum, bebas, rahasia, jujur dan adil atau biasa disingkat asas luber jurdil. ${ }^{12}$ Asas tersebut dapat dijabarkan sebagai berikut:

a. Langsung, artinya setiap warga negara dapat menggunakan hak pilihnya secara langsung. Rakyat pemilih mempunyai hak untuk memilih secara langsung

\footnotetext{
${ }^{8}$ Soerjono Soekanto, sosiologi suatu pengantar, (Raja Grafindo Persada,2002), Hlm.441.

${ }^{9}$ Pasal 1 ayat (1) Undang-undang Nomor 7 tahun 2017 tentang Pemilihan Umum

${ }^{10}$ Soewoto Mulyosudarmo, Pembaharuan Ketatanegaraan Melalui Perubahan Konstitusi, Asosiasi

Pengajar HTN dan HAN dan In-TRANS, Malang, 2004, hlm. 4

${ }^{11}$ Moh. Kusnardi dan Harmailly Ibrahim, Pengantar Hukum Tata Negara, hlm. 328.

${ }^{12}$ Pasal 1 ayat 1 Undang-undang Nomor 7 tahun 2017 tentang Pemilihan Umum.
} 
memberikan suaranya menurut hati nuraninya tanpa perantara dan tanpa tingkatan

b. Umum, artinya setiap warga negara Indonesia yang sudah memenuhi syarat sebagai pemilih mempunyai hak untuk memberikan suaranya

c. Bebas, artinya setiap pemilih bebas memilih pemimpin sesuai hati nuraninya. Setiap pemilih berhak memilih dalam menggunakan hak pilihnya dijamin keamanannya untuk melakukan pemilihan menurut hati nuraninya tanpa adanya pengaruh, tekanan atau paksanaan dari siapapun/dengan apapun

d. Rahasia, artinya pilihan pemimpin yang dipilih oleh setiap warga negara berhak dirahasiakan, dan dijamin oleh peraturan perundangan

e. Jujur, artinya setiap warga negara berhak memilih bakal calon pemimpin secara jujur sesuai pilihan hati nuraninya tanpa pengaruh dari pihak lain

f. Adil, artinya setiap warga negara memiliki kesempatan yang sama dalam menggunakan hak pilihnya.

4.

Tujuan Pemilihan Umum

Secara menyeluruh, tujuan penyelenggaraan pemilu itu ada 4 (empat) yaitu: ${ }^{13}$

a. untuk memungkinkan terjadinya peralihan kepemimpinan pemerintahan secara tertib dan damai;

b. untuk memungkinkan terjadinya pergantian pejabat yang akan mewakili kepentingan rakyat di lembaga perwakilan;

c. untuk melaksanakan prinsip kedaulatan rakyat; dan

d. untuk melaksanakan prinsip hak-hak asasi warga negara.

Harus dimaklumi, kemampuan seseorang dalam melaksanakan apapun adalah bersifat terbatas. Di samping itu pula, jabatan pada dasarnya merupakan amanah yang berisi beban dan tanggung jawab, bukan merupakan hak yang harus dinikmati. Jadi, sudah seharusnya seseorang tidak boleh menduduki suatu jabatan tanpa ada kepastian berapa lama ia duduk di jabatan tersebut. Dibutuhkan suatu siklus jabatan yang dinamis untuk mencegah kekuasaan yang permanen dan menjadi sumber malapetaka, hal ini dikarenakan dalam setiap jabatan, dalam dirinya selalu ada kekuasaan yang cenderung berkembang menjadi sumber kesewenang-wenangan bagi siapa saja yang memegangnya. Untuk itulah, pergantian kepemimpinan harus dipandang sebagai suatu keniscayaan untuk memelihara amanah yang terdapat dalam setiap kekuasaan itu sendiri.

Dalam pemilihan umum, yang dipilih tidak saja wakil rakyat yang akan duduk di lembaga perwakilan rakyat atau parlemen, tetapi juga para pemimpin pemerintahan yang duduk di kursi eksekutif. Di cabang kekuasaaan legislatif, para wakil rakyat itu ada yang duduk di Dewan Perwakilan Rakyat, Dewan Perwakilan Rakyat Daerah baik di tingkat provinsi maupun kabupaten/kota, dan ada yang duduk di Dewan Perwakilan Daerah. Sementara itu di cabang kekuasaan eksekutif, para pemimpin yang dipilih secara langsung oleh rakyat adalah Presiden dan Wakil Presiden, Gubernur dan Wakil Gubernur, Bupati dan Wakil Bupati, serta Walikota dan Wakil Walikota. Dengan terlaksananya pemilu yang teratur dan berkala maka pergantian pejabat yang dimaksud juga berjalan secara teratur dan berkala pula. ${ }^{14}$

${ }^{13}$ Jimly Asshiddiqie,Pengantar Ilmu Hukum Tata Negara, Sekertariat Jenderal dan Kepaniteraan Mahkamah Konstitusi, Jakarta, 2006, hal. 418-419.

${ }^{14}$ Jimly Asshiddiqie, ibid, hal. 419 


\section{ANALISIS PERAN KOMISI PEMILIHAN UMUM DALAM PENETAPAN DAFTAR PEMILIH TETAP PADA PEMILU SERENTAK TAHUN 2020- Faharudin}

Hak-hak politik rakyat untuk menentukan jalannya pemerintahan dan fungsifungsi negara secara dengan benar dan sebaik-baiknya menurut Undang-undang Dasar adalah hak konstitusional warga negara dan merupakan hak yang sangat fundamental. Oleh karena itu penyelenggaraan pemilu, di samping merupakan perwujudan kedaulatan rakyat, juga merupakan sarana pelaksanaan hak-hak asasi warga negara sendiri.

Demikian pula di lingkungan kekuasaan eksekutif, rakyat sendirilah yang harus memilih Presiden, Gubernur, Bupati, dan Walikota untuk memimpin jalannya pemerintahan baik di tingkat pusat, di tingkat provinsi, maupun di tingkat kabupaten/kota.

5.

Sistem Pemilihan Umum

Tentang sistem pemilihan umum, dilihat dari kedudukan individu rakyat, maka terdapat sistem pemilihan mekanis dan sistem pemilihan organis. Sistem mekanis melihat bahwa rakyat terdiri atas individu-individu di mana hak suara berada pada masing-masing individu. Sedangkan pada sistem organis, rakyat ditempatkan sebagai sejum1ah ke1ompok individu atau dengan perkataan lain rakyat dibagi dalam organorgan kelompok individu. Kelompok ini didasarkan misalnya geneologis, lapisan sosial, organisasi kelembagaan, dan sebagainya. Dengan demikian pada sistem organis hak suara terletak pada kelompok. ${ }^{15}$

Kemudian daripada itu sistem pemilihan mekanis dalam pelaksanaannya dilakukan dengan dua cara yaitu sistern perwakilan distrik/mayoritas/singIe member constituencies, dan sistem perwakilan proporsional. Pada sistem distrik wilayah negara dibagi dalam distrik-distrik pemilihan/ daerah/ daerah pemilihan/ constituencies yang jumlahnya sarna dengan jumlah anggota badan perwakilan rakyat. Tiap distrik diwakili oleh seorang wakil, karena itu dinamakan juga sistem mayoritas karena untuk menentukan wakil terpilih dari suatu distrik ditentukan menurut calon mana yang memperoleh suara terbanyak. Sedangkan sistem proposional ialah sistem di mana persentase kursi di badan perwakilan rakyat yang akan dibagikan kepada tiap-tiap partai politik, disesuaikan dengan persentase jumlah suara yang diperoleh tiap-tiap partai politik itu.

Sistem proporsional ini dapat dilakukan dengan bervariasi, misalnya dengan hare system dan list system. Hare system, di mana pemilih di-beri kesempatan untuk memilih pilihan pertama, kedua dan seterusnya, dari distrik pemilihan yang bersangkutan. Jum1ah imbangan suara yang diperlukan untuk pemilih ditentukan, dan segera jum1ah keutamaan pertama dipenuhi, dan apabila ada sisa suara, maka ke1ebihan ini dapat dipindahkan kepada calon berikutnya, dan seterusnya.

Berkaitan dengan pemilu 2020 yang merupakan Pemilu serentak memiliki landasan hukum sebagai pijakan pelaksanaannya. Landasan hukumnya adalah UU Nomor 7 Tahun 2017 tentang Pemilihan Umum. UU ini terdiri atas 573 Pasal, penjelasan dan 4 lampiran. UU ini juga merupakan penyederhanaan dan penggabungan dari tiga buah undang-undang sebelumnya, yakni UU Nomor 42 Tahun 2008 tentang Pemilhan Umum Presiden dan Wakil Presiden, UU Nomor 15 Tahun 2011 tentang penyelenggaraan Pemilihan Umum, dan UU Nomor 8 Tahun 2012 tentang Pemilihan Umum Anggota Dewan Perwakilan Rakyat, Dewan Pewakilan

\footnotetext{
${ }^{15}$ Moh. Kusnardi dan Harmailly Ibrahim, Pengantar Hukum Tata Negara,hIm. 333-335.
} 
Daerah, dan Dewan Perwakilan Rakyat Daerah.

Undang-Undang Nomor 7 Tahun 2017 tentang Pemilihan Umum ini, setidaknya memuat lima point utama, yakni: ${ }^{16}$

a. Sistem Pemilu Terbuka

Sistem ini merupakan sistem yang cenderung membebaskan pemilih untuk memilih calon yang diinginkannya, sistem ini banyak diusulkan oleh pengamat pemilu karena dinilai lebih demokratis dan menambah tingkat partisipasi masyarakat karena mereka bisa memilih langsung dan bebas wakilnya.

b.

Presidential Threshold

Poin ambang batas pencalonan presiden ini adalah poin yang paling memantik perdebatan, yang akhirnya diputuskan 20-25\%, yakni 20\% suara kursi di DPR atau 25\% suara sah nasional. Namun ada yang berpendapat bahwa Ketentuan ambang batas pencalonan presiden bertentangan dengan Pasal 6A ayat (2) UUD NRI 1945,yang menjamin hak setiap partai politik peserta Pemilu bisa mengajukan pasangan calon Presiden. Secara politik, ketentuan ambang batas pencalonan Presiden juga akan dianggap membatasi kesempatan partai atau warga negara lain maju menjadi pasangan calon Presiden.

c. Parliamentary Threshold

Ambang batas parlemen yang disahkan ialah 4\%, naik 0.5\% dari pemilu tahun2014 yang lalu, sehingga partai yang perolehannya tidak mencapai 4\% pada pemilihan legislatif tak akan lolos sebagai anggota DPR RI, DPR Provinsi maupun DPRD Kabupaten/Kota. Poin ini telah disepakati olesemua fraksi di parlemen, berbeda dengan Presidential Threshold yang dianggap sudah tidak relevan karena pemilu 2019 dilaksanakan serentak.

d. Metode Konversi Suara

Dalam perubahan suara menjadi kursi, metode Sainte Lague modifikasi membagi jumlah suara tiap partai di suatu dapil dengan empat angka konstanta sesuai rumus. Konstanta awalnya dimulai dengan angka satu kemudian dilanjutkan dengan bilangan ganjil selanjutnya, setelah itu hasilnya diperingkatkan sesuai dengan jumlah kursi dalam suatu dapil. Metode ini baru diterapkan di Indonesia. Sebelumnya Indonesia menggunakan metode bilangan pembagi pemilih (BPP). Metode Sainte Lague dinilai lebih adil, karena partai yang memiliki perolehan suara besar akan memiliki jatah kursi yang besar pula.

e.

Alokasi kursi per dapil

Poin alokasi kursi per dapil diputuskan 3-10, artinya jumlah minimum kursi dalam sebuah dapil adalah tiga kursi, sedangkan sepuluh adalah angka maksimumnya. Poin ini memiliki kesamaan dengan poin terdahulu.

\section{PEMBAHASAN}

Agar tercipta daftar pemilih yang akurat, komperhensif dan terkini, Komisi Pemilihan Umum Daerah sebagai penyelenggara pemilihan umum berkomitmen kuat untuk melakukan pemutakhiran dan penyusunan Daftar Pemilih yang lebih baik, karena daftar pemilih yang berkualitas akan mendorong kualitas proses dan hasil pemilu lebih baik. Sebaliknya, jika dalam penetapan daftar pemilih ditemukan banyak permasalahan maka

16 http://www.calonsh.com/2017/09/05/penyederhanaan-sistem-pemilu-melalui-uu-no- 7-tahun2017 


\section{ANALISIS PERAN KOMISI PEMILIHAN UMUM DALAM PENETAPAN DAFTAR PEMILIH TETAP PADA PEMILU SERENTAK TAHUN 2020- Faharudin}

proses dan hasil pemilu dapat dipertanyakan legitimasinya

Dalam penetapan daftar pemilih tetap, Komisi Pemilihan Umum Daerah kota baubau tidak bekerja sendiri, Komisi Pemilihan Umum Daerah Kota Baubau dibantu oleh Panitia Pemilihan Kecamatan (PPK), Panitia Pemungutan Suara (PPS), dan Petugas Pemutakhiran Daftar Pemilih (PANTARLIH).

Tahapan pemutakhiran data dan daftar pemilih adalah salah satu tahap terpenting di dalam pemilihan umum, pemutakhiran daftar pemilih untuk pemilihan umum di atur di dalam Peraturan Komisi Pemilihan Umum Nomor 11 Tahun 2018 tentang penyusunan daftar pemilih di dalam negeri dalam penyelenggaraan pemilihan umum, menurut pasal 1 ayat 39 Peraturan Komisi Pemilihan Umum Nomor 11 Tahun 2018 tentang Penyusunan daftar pemilih di dalam negeri yang dimaksud dengan pemutakhiran Data Pemilih adalah kegiatan untuk memperbarui data pemilih berdasarkan daftar pemilih tetap dari pemilu atau pemilihan terakhir yang di mutakhirkan secara berkelanjutan dan disandingkan dengan DP4 serta dilakukan pencocokan dan penelitian yang dilaksanakan oleh KPU/KIP Kabupaten/Kota dengan dibantu oleh PPK,PPS, dan Pantarlih.

Tahap pemutakhiran Daftar Pemilih Tetap adalah tahapan terlama selama proses Pemilihan Umum serentak 2019. Menilik PKPU NO 10 tahun 2019 tentang tahapan,program, dan jadwal penyelenggaraan pemilihan umum tahun 2019 Pada bulan Desember 2017 dimulai proses Pemutakhiran Daftar Pemilih Tetap dan tahapan ini berakhir pada bulan Agustus 2018 dalam rapat pleno penetapan rekapitulasi Daftar Pemilih Tetap yang dilakukan Komisi Pemilihan Umum Daerah Kota Baubau. ${ }^{17}$

1.

Penyediaan Data Kependudukan Dan Pemutakhiran Daftar

\section{Pemilih}

Untuk menetapkan Daftar Pemilih Tetap Komisi Pemilihan Umum Republik Indonesia melakukan koordinasi dengan Kementerian Dalam Negeri, Komisi Pemilihan Umum Republik Indonesia menerima Data Penduduk Potensial Pemilih Pemilu (DP4) dari Kementrian Dalam Negeri, untuk disinkronkan dengan Daftar Pemilih Tetap Pemilihan Presiden tahun 2014. Menurut pasal 1 ayat 31 Peraturan Komisi Pemilihan Umum Nomor 11 Tahun 2018 Tentang penyusunan daftar pemilih yang dimaksud dengan DP4 adalah data yang disediakan oleh pemerintah berisikan data penduduk yang memenuhi persyaratan sebagai Pemilih pada saat Pemilihan diselenggarakan.

DP4 yang sudah di sinkronkan oleh Komisi Pemilihan Umum Republik Indonesia kemudian diturunkan kepada Komisi Pemilihan Umum Daerah Kota Baubau melalui KPU Provinsi untuk dilakukan pencocokan dan penelitian. DP4 yang diperoleh Komisi Pemilihan Umum Kota Baubau adalah data mentah yang harus diolah kembali karena banyak yang tidak sesuai dengan ketentuan syarat pemilih, seperti pemilih yang tidak dikenal, pemilih yang sudah pindah tempat tinggal, pemilih yang sudah meninggal dunia, pemilih yang masih dibawah umur atau pemilih yang memiliki status sebagai anggota TNI/POLRI.

DP4 yang diterima oleh Komisi Pemilihan Umum Daerah Kota Baubau kemudian dipetakan kembali, pemetaan ini dilakukan oleh PPS, data pemilih yang telah di petakan oleh PPS ini kemudian dibagi lagi kedalam TPS-TPS untuk dilakukan validasi terhadap data pemilih. Kemudian dilakukan pencocokan kembali (Coklit) untuk mengurangi pemilih yang tidak memenuhi syarat dan memasukkan pemilih yang sudah memenuhi syarat.

\footnotetext{
${ }^{17}$ Peraturan Komisi pemilihan Umum No 10 tahun 2019 tentang tahapan,program, dan jadwal penyelenggaraan pemilihan umum tahun 2019
} 
Setelah proses coklit selesai sanjutnya dilakukan penyusunan Daftar Pemilih hasil pemutakhiran dengan tahapan sebagai berikut :

1. PPS mengumpulkan dan mengkoordinasikan hasil verifikasi data pemilih oleh PANTARLIH setelah coklit selesai

2. Setelah PPS memastikan semua hasil coklit telah lengkap diterima, PPS segera menyusun daftar pemilih hasil pemutakhiran

3. Memeriksa hasil cooklit PANTARLIH dan meminta penjelasan jika terdapat sesuatu yang tidak lengkap atau tidak dimengerti oleh PPS

4. PPS wajib menyusun daftar hasil pemutakhiran

Sebelum ditetapkannya Daftar Pemilih Sementara, PPS melakukan Pleno rekapitulasi Daftar Pemilih Hasil Pemutakhiran, Pleno rekapitulasi daftar pemilih hasil pemutakhiran dilaksanakan oleh PPS paling lambat 3 hari setelah penyusunan daftar pemilih hasil pemutakhiran selesai dilaksanakan, dalam Pleno PPS mengundang PANTARLIH, PANWASLU Kelurahan/Desa, peserta pemilu tingkat Kelurahan/Desa dan perangkat pemerintah tingkat Kecamatan/Desa.

PPS juga memperbaiki Daftar Pemilih Hasil Pemutakhiran jika terdapat usulan perbaikan yang disertai dengan bukti yang kuat dan harus disertai dengan akta autentik dan bukti tertulis berupa nama Pemilih, Tanggal lahir Pemilih dan Lokasi TPS. Ketua dan anggota PPS menandatangani dan membubuhkan stempel basah berita acara rapat pleno rekapitulasi daftar pemilih hasil pemutakhiran. Panitia Pemungutan Suara menyampaikan berita acara (BA) rapat pleno dan rekapitulasi daftar pemilih hasil pemutakhiran kepada Panitia Pemilih Kecamatan, panwaslu kelurahan/desa,peserta pemilu kelurahan/desadan perangkat pemerintah tingkat kelurahan/desa.

Dari hasil rekapitulasi daftar pemilih pemutakhiran oleh PPS selanjutnya naik ke tingkat PPK dengan merekapaitulasi dalam rapat pleno terbuka dan dituangkan ke dalam berita acara yang di tandatangani oleh ketua dan anggota PPK. Dalam rapat pleno tersebut di hadiri oleh PPS, PANWASLU tingkat Kecamatan, peserta pemilu Kecamatan, dan perangkat pemerintah tingkat kecamatan serta dapat memerikan masukan dan tanggapan dengan bukti autentik. ${ }^{40}$

\section{Daftar Pemilih Sementara}

Data yang telah dilakukan validasi kemudian menjadi Daftar Pemilih Sementara yang disahkan oleh Komisi Pemilihan Umum Daerah Kota Baubau dalam rapat Pleno Penetapan Daftar Pemilih Sementara dan di unggah kedalam portal sidalih (sistem informasi data pemilih) menurut Peraturan Komisi Pemilihan Umum Nomor 11 tahun 2018 tentang penyusunan daftar pemilih dalam negeri, sidalih (sistem data pemilih) adalah sistem elektronik dan teknologi informasi yang digunakan untuk proses kerja penyelenggara pemilu atau pemilihan dalam menyusun, mengumumkan dan memelihara data pemilih.

Tahap selanjutnya adalah pengumuman dan perbaikan Daftar Pemilih Sementara yang dilakukan oleh Panitia Pemungutan Suara, tahap pengumuman dan perbaikan Daftar Pemilih Sementara antara lain:

a. Setelah menerima Daftar Pemilih Sementara dari Komisi Pemilhan Umum Kabupaten/Kota, Panitia Pemungutan Suara mengumumkan DP di tempat yang mudah dijangkau masyarakat selama 14 hari

b. Masyarakat, pengawas pemilu dan atau peserta pemilu dapat menyampaikan masukan dan tanggapan terhadap DPS paling lama 21 


\section{ANALISIS PERAN KOMISI PEMILIHAN UMUM DALAM PENETAPAN DAFTAR PEMILIH TETAP PADA PEMILU SERENTAK TAHUN 2020- Faharudin}

hari sejak DPS di umumkan.

c. PPS wajib memperbaiki DPS bersadarkan masukan dan tanggapan tersebut.

Dari perbaikan DPS tersebut PPS menyusun dan merekapitulasi daftar pemilih sementara hasil perbaikan dalam rapat pleno terbuka kemudian di serahkan kepada KPU Kab/kota melalui PPK sebagai bahan penyusunan DPSHP dalam SIDALIH. ${ }^{18}$

\section{3. \\ Daftar Pemilih Sementara Hasil Perbaikan}

KPU kabupaten kota menetapkan dan merekapitulasi DPSHP dari PPK dalam rapat pleno terbuka yang dihadiri oleh PPK,BAWASLU Kab/kota,peserta pemilu tingkat daerah kabupaten/kota dan perangkat pemerintah tingkat kabupaten kota. Setelah perekapan DPSHP tahap selanjutnya ialah diumumkan kembali oleh PPS pada tempat yang mudah dijangkau untuk mendapat masukan dan tanggapan masyarakat atau peserta pemilu selama 7 hari, dari pengumuman DPSHP tersebut jika ada tanggapan dan masukan maka PPS wajib memperbaiki. Dari hasil perbaikan DPSHP dihasilkan DPSHP akhir dan di rekapitulasi oleh PPS yang selanjutnya di serahkan ke KPU Kab/kota melalui PPK guna penetapan DPT. ${ }^{19}$

\section{Daftar Pemilih Tetap}

pada tahap ini KPU Kab/kota menerima rekapitulasi DPSHP akhir dari PPK agar di rekapitulasi dan di tetapkan sebagai DPT, dalam penetapan DPT dilakukan dalam rapat pleno terbuka dan di tuangkan ke dalam berita acara yang ditandatangani oleh ketua dan anggota KPU Kab/kota, rapat pleno sebagaimana di maksud di hadiri oleh PPK, BAWASLU Kab/kota, peserta pemilu tingkat daerah Kab/kota, dan perangkat pemerintah tingkat kabupaten/kota, dalam rapat pleno tersebut peserta rapat dapat memberikan masukan apabila terdapat kekeliruan dalam rekapitulasi. ${ }^{43}$

\section{KESIMPULAN}

Kesimpulan yang dapat diperoleh adalah Peran Komisi Pemilihan Umum Daerah dalam Penetapan Daftar Pemilih tetap (DPT) yaituh memutakhirkan, menyusun, hingga menetapkan Daftar Pemilih Tetap dimana dalam prosesnya cukup panjang dan berjenjang antara proses satu dengan lainnya, dimulai dari penyandingan daftar pemilih terakhir dengan DP4 hasil sinkronisasi oleh KPU, yang selanjutnya di lakukan pemutakhiran data pemilih oleh PANTARLIH, kemudian oleh PPS menyusun dan memutakhirkan Daftar Pemilih Sementara (DPS) Setelah penetapan DPS oleh KPUD selanjutnya tahap pengumuman dan perbaikan DPS dan di hasilkanlah DPSHP, begitu juga berlaku pada DPSHP hingga terbentuklah DPSHP Akhir, dari DPSHP Akhir ini kemudian oleh KPUD merekapitulasi dan di tetapkanlah Daftar Pemilih Tetap (DPT).

\section{DAFTAR PUSTAKA}

\section{A. Buku}

Abdulsyani. 2012. Sosiologi: Skematika,Teori dan Terapan, Jakarta:PT Bumi Aksara. Amalia, Luki Sandra, Syamsuddin Haris, Sri nur yanti, Lili Romli, dan Devi Darmawan, 2016, Evealuasi Pemilu Legislatif 2014 Analisi Proses dan Hasil.

\footnotetext{
${ }^{18} \mathrm{Ibid}$

${ }^{19} \mathrm{Ibid}$
} 
Yogyakarta:Pustaka Belajar

Asshiddiqie, Jimly. 2006. Pengantar Ilmu Hukum Tata Negara, Jakarta: Sekertariat Jenderal dan Kepaniteraan Mahkamah Konstitusi

Budiardjo, Miriam. 2008. Dasar-dasar Ilmu Politik. Jakarta, PT. Gramedia Pustaka.

Djogo Tony, dkk. 2003. Kelembagaan dan Kebijakan Dalam Pengembangan Agroforestri. Bogor: World Agroforestry Centre (ICRAF).

Kusnardi, Moh. \& Ibrahim, Harmaily.1983, Hukum Tata Negara Indonesia, Jakarta:Sinar Bakti.

Mukthie, Fadjar. 2013. Pemilu, Perselisihan Hasil Pemilu dan Demokrasi. Malang: Setara Press.

Mulyosudarmo, Soewoto, 2004, Pembaharuan Ketatanegaraan Melalui Perubahan Konstitusi, In Trans Publishing, Malang.

Pusat Bahasa. 1997. Kamus Besar Bahasa Indonesia. Jakarta: Gramedia Pustaka Utama.

Soekanto,Soerjono.2002. Sosiologi Suatu Pengantar, Raja Grafindo Persada.

Sitti, Bulkis. 2011. Manajemen Pembangunan, Makasar:Universitas Hasanudin.

\section{B. Peraturan Perundang Undangan}

Undang-Undang Dasar Negara Republik Indonesia Tahun 1945. Undang-Undang Nomor 7 tahun 2017 tentang Pemilihan Umum.

Peraturan Komisi Pemilihan Umum Nomor 11 Tahun 2018 Tentang Penyusunan Daftar Pemilih Di Dalam Negeri Dalam Penyelenggaraan Pemilihan Umum.

Peraturan Komisi Pemilihan Umum Nomor 10 Tahun 2019 Tentang Tahapan, Program Dan Jadwal Penyelenggaraan Pemilihan Umum Tahun 2019.

\section{Jurnal}

Hutami Gartiria, Pengaruh Konflik Peran dan Ambiguitas Peran Terhadap Komitmen Independensi Auditor Internal Pemerintah Daerah (Studi Empiris Pada Inspektorat Kota Semarang) (Universitas Diponegoro, Jurnal).

\section{Internet}

http://www.kpu-baubaukota.go.id/tugas-dan-wewenang.html (Di akses 20 Maret 2021, pukul 22.13 wita)

http://www.calonsh.com/2017/09/05/penyederhanaan-sistem-pemilu-melalui-uu-no-7tahun-2017 (Di akses 24 april 2021, pukul 12.46 wita)

https://kumparan.com/@kumparannews/3-kategori-pemilih-di-pemilu-2019-dpt-dptb- dan$d p k$-1pzEapKZaZ4 (Di akses 18 mei 2021, pukul 10.20 wita) 